\title{
Paringin Pit Lake: Key Success Factors of Creating a Pit Lake of Ex- Coal Mined Pit
}

\author{
D. Triwibowo', T. Roberts², C.C. Lee ${ }^{3}$ \\ ${ }^{1} \mathrm{PT}$ Adaro Indonesia \\ PT Adaro Indonesia Haul Road KM 73, Tabalong, South Kalimantan, Indonesia \\ didik.triwibowo@adaro.com \\ ${ }^{2}$ School of Environmental and Life Sciences, University of Newcastle (Australia), Newcastle, Australia \\ tim.roberts@newcastle.edu.au \\ ${ }^{2}$ Newcastle Australia Institute of Higher Education, Singapore. \\ charles.cc.lee@newcastle.edu.au
}

\section{Extended Abstract}

PT Adaro Indonesia (Adaro) is a coal mining company located in Tabalong and Balangan Regency, South Kalimantan Province, Indonesia. Adaro produces 50 million tons of coal annually from 3 (three) open pits operation: Paringin, Tutupan and Wara pit within its concession area with total land used for mining operation approximately 20,000 ha for open pit, waste dump area and mining infrastructure (settling ponds, roads, workshops). Approximately 2,500 Ha area out of 20,000 Ha is already rehabilitated and revegetated. Adaro open pit operation is located in the area with high rainfall intensity approximately 3,000 - 4,000 $\mathrm{mm}$ annually. The combination of extensive open pit operation and high rainfall intensity resulted in huge volume of mine water that need to be treated before it can be discharged into receiving river.

Another future challenge is related to the void that will be created after cessation of open pit operation. There will be 6 (six) major pit lakes created at the end of mine in 2042 that has total area ranged from 131 hectares to 1,450 hectares for the biggest pit lake. Currently, there is one small pit lake already created with total area 20 hectares in southern part of Paringin pit as a result of in pit backfill. This 20 hectares of Paringin pit lake already achieved stable condition geotechnically of the void, geochemically in term of there is no acid mine drainage generation and stable catchment condition (approximatey 150 hectares) after revegetation that resulted in a good water quality of pit lake. The healthy pit lakes characterized by active hydrologic process (flow through process) of water, near neutral pH of water with low TSS (Total Suspended Solid), low concentration of trace metals and stable Dissolved Oxygen concentration (above $4 \mathrm{mg} / \mathrm{l}$ ) that is suitable for aquaculture.. Today, the Paringin Pit Lake become a habitat of various local fishes species and other creatures including birds as well as the source of water resources for receiving river body, Nungkaran River. This condition is a result of long term preparation of finalizing final void shape and progressive revegetation since 2009.

The key success factors for creating healthy and functional pit lakes from ex coal mined are: creating stable final void shape in term of slope stability of pit wall, carefully managing and covering PAF (Potentially Acid Forming) waste dump material with NAF (Non Acid Forming) material so the acid mine drainage can be prevented, conducting progressive revegetation process of pit lake's catchment so the erosion and sedimentation from runoff of rainfall can be minimized so the water entering the pit lake will have low TSS concentration. The future plan for existing Paringin pit lake is to develop it into more productive used such as eco-tourism and fresh water fishery. 